\title{
Productivity of Chickpea (Cicer arietinum L.) under Different Sowing Date and Seed Rate in South West Punjab
}

\author{
Amrinder Singh, Balwinder Singh Dhillon " and Ajmer Singh Sidhu \\ College of Agriculture, Guru Kashi University, Talwandi Sabo, India \\ *Corresponding author
}

\section{Keywords \\ Chickpea, Date of sowing, Flowering, Seed rate and seed yield \\ Article Info \\ Accepted: \\ 12 April 2019 \\ Available Online: \\ 10 May 2019}

\section{A B S T R A C T}

A field experiment entitled "Effect of date of sowing and seed rate on growth and yield of chickpea (Cicer arietinum L.)" was conducted at the Research Farm of Guru Kashi University, Talwandi Sabo during rabi season 2016-17 and 2017-18. The experiment was conducted in split plot design with combinations of three date of sowing viz., Oct 10, Oct 25 and Nov 10 in main plots and three seed rates viz., 37.5, 62.5 and $87.5 \mathrm{~kg} / \mathrm{ha}$ in sub plots, replicated thrice. The results showed that the crop sown on Oct 25th recorded maximum plant population $/ \mathrm{m}^{2}(15.2)$, plant height $(61.2 \mathrm{~cm})$, number of primary branches/plant (4.1), number of fruit branches/plant (17.2), number of pods/plant (144.7), number of grains/pod (1.90), 1000-grain weight (160.4 g), seed yield (20.1 q/ha), haulm yield (30.2 q/ha), biological yield (50.3 q/ha) and harvest index (39.9\%) than other date of sowing (Oct 10th \& Nov 10th). Days taken to 50\% flowering (101.4) and days taken to maturity (160.7) were significantly higher in Oct 10 sowing date than other sowing dates (Oct 25th and Nov 10th). Similarly, seed rate @ $62.5 \mathrm{~kg} / \mathrm{ha}$ recorded significantly higher plant height $(61.6 \mathrm{~cm})$, number of primary branches (4.0), number of fruit branches (16.6), number of pods/plant (138.7), number of grains/pod (1.92), 1000-grain weight (161.0 g), seed yield (20.4 q/ha), biological yield (48.9 q/ha) and harvest index (41.7\%) as compared to other seed rates i.e. 37.5 and $87.5 \mathrm{~kg} / \mathrm{ha}$. Plant population $/ \mathrm{m} 2(17.8)$, days taken to $50 \%$ flowering (98.2), days taken to maturity (158.4) and haulm yield (29.9 q/ha) significantly increase using seed rate $87.5 \mathrm{~kg} / \mathrm{ha}$. Crop sown on Oct 25 th with seed rate @ $62.5 \mathrm{~kg} / \mathrm{ha}$ (D2S2) registered significantly higher in plant height (64.5), number of pods/plant (149.5), number of grains/pod (2.14), 1000-grain weight (164.6 gm), seed yield (22.1 q/ha), biological yield (52.2 q/ha) and harvest index (42.6\%) than other treatments.

\section{Introduction}

Chickpea (Cicer arietinum L.), the most important pulse crop of rabi season, is cultivated mainly in semi-arid and warm temperate regions of the world. It is grown in several countries worldwide as a food source. It is, probably, the highest protein containing gram legume expect groundnut and soybean.
Chickpea is the third most important food legume crop and India is the largest producer contributing to $65 \%$ of world's chickpea production (FAOSTAT, 2008). Even though India is the largest producer of chickpea; it still imports chickpea from other countries. Chickpea is largely cultivated in the temperate region. 
Chickpea is a premier pulse crop of India grown in rabi season under various cropping systems. In India, it is grown on an area about 9.91 million hectares with an annual production of 8.22 million tones and average productivity is $895 \mathrm{~kg} / \mathrm{ha}$. It contributes about $47 \%$ of the total pulse production and about $40 \%$ of total pulse growing area in the country. In India, it is mainly grown in the states of Andhra Pradesh, Bihar, Gujarat, Haryana, Karnataka, Madhya Pradesh, Maharashtra, Rajasthan, Uttar Pradesh, etc. Among these states, Madhya Pradesh is the largest producer of chickpea, which covers 2.79 million hectares area with an annual production of 2.58 million tonnes. Chickpea is an important source of protein in the diets of the poor and is particularly important in vegetarian diets. Also, it is being used increasingly as a substitute for animal protein. Optimum sowing time of chickpea may vary from one variety to another and also from one region to another due to variation of agroecological conditions.

In Punjab chickpea is usually sown between mid October to mid November. However, sowings are often delayed when grown in sequence with kharif crops. The exposure of crop to low temperatures during germination and seedling establishment and to high temperature during flowering and seed formation phases under delay-sown chickpea results in drastic reduction in yield. Yield loss in chickpea can vary between 30 and $60 \%$ depending on genotype, sowing time, location, and climatic conditions during sowing season. Some chickpea genotypes have capacity to tolerate drought and in that case sowing time can be delayed. However, earlier or late sowing caused drastic reduction in yield and net profit compared with timely sowing. Among the various production factors an optimum seed rate is prime importance as it directly affects the micro environment and growth pattern of individual crop plant and thereby yield. Appropriate seed rate would provide more efficient use of available resources, via, soil moisture, and nutrient will allow a crop to exert greater inter-specific completion. The present study was undertaken to find out the most suitable sowing date as well as seed rate for improving chickpea production.

\section{Materials and Methods}

The present investigation "Effect of date of sowing and seed rate on growth and productivity of chickpea" was conducted at Research Farm of Guru Kashi University Talwandi Sabo, Bathinda during rabi season 2016-17 and 2017-18. Talwandi Sabo is situated at $29^{0} 57^{\prime} \mathrm{N}$ latitude and $75^{\circ} 7^{\prime} \mathrm{E}$ longitude at a height of 213 meters above the sea level. The climate of the experimental site is characterized by semi-arid type with hot and dry summer from April to June, hot and humid from July to September and cold winter from November to January. The maximum temperature $24.8^{\circ} \mathrm{C}$ was recorded in the month of June and minimum temperature $18.4^{\circ} \mathrm{C}$ recorded in the month of April. Maximum relative humidity (morning) (90.7\%) was recorded during the month of January. Maximum rainfall $(14.0 \mathrm{~mm})$ was recorded in the month of November. The soil of the experimental plot was sandy loam with a $\mathrm{pH}$ of 7.8 , low in organic carbon $(0.34 \%)$, low in available $\mathrm{N}\left(125.4 \mathrm{~kg} \mathrm{ha}^{-1}\right)$, medium in available $\mathrm{P}\left(13.9 \mathrm{~kg} \mathrm{ha}^{-1}\right)$ and high in available $\mathrm{K}\left(245.6 \mathrm{~kg} \mathrm{ha}^{-1}\right)$. The experiment was laid out in split plot design. The experiment was conducted in split plot design with combinations of three date of sowing viz., Oct 10, Oct 25 and Nov 10 in main plots and three seed rates viz., 37.5, 62.5 and 87.5 $\mathrm{kg} / \mathrm{ha}$ in sub plots, replicated thrice.

During the crop growth period, the following observations were recorded from time to time. Total number of plants was recorded from 
each plot. The height of five randomly selected plants was measured at the maturity. The total no of branches (primary and fruiting) were counted from the five randomly selected plants in each plot at maturity stage and the average value was worked out. The $50 \%$ flowering time was recorded from each plot at the flowering stage counting the flowering plants and it divided by the total no. of the plant population from each plot. The period taken for 50 percent flowering under different treatments was recorded from each plot. The total number of pods per plant was recorded from the 5 randomly selected plants from each plot. After threshing the bunch of five plants, the number of seeds were counted and divided with total number of pods recorded from these five plants to obtain number of seeds/pod. The weight of 1000 grains was recorded from each plot and expressed in gram (g). Number taken to maturity days were counted from each plot after the coluor of the plant and pod turned yellow. After threshing of crop, the data on grain and haulm yield was recorded from each plot and expressed as $\mathrm{kg} / \mathrm{ha}$. The total biomass was recorded after complete drying of the plant from each plot. Harvest index (HI) was calculated by using following formula:

Harvest index $(\%)=\frac{\text { Seed yield }}{\text { Biological yield }} \times 100$

Fisher's ANOVA technique and least significant difference (LSD) test at 5\% probability level was used to compare differences among treatment means (Steel et al., 1997).

\section{Results and Discussion}

\section{Growth parameters}

Significantly highest plant population was recorded with seed rate of $87.5 \mathrm{~kg} / \mathrm{ha}$ than other seed rate treatments i.e. 37.5 and 62.5 $\mathrm{kg} / \mathrm{ha}$ (Table 1). Maximum plant population was observed in chickpea sown on Oct $25^{\text {th }}$ than other sowing dates i.e. Oct $10^{\text {th }}$ and Nov $10^{\text {th }}$. The increase in plant population may be attributed to more number of plants per unit area and soil moisture availability. The interaction effect of date of sowing and seed rate was found to be non-significant for the plant population.

Significantly highest plant height was recorded with seed rate of $62.5 \mathrm{~kg} / \mathrm{ha}$ than other seed rate treatments i.e. 37.5 and 87.5 $\mathrm{kg} / \mathrm{ha}$. Maximum plant height was observed in chickpea sown on Oct $25^{\text {th }}$ than other sowing dates i.e. Oct $10^{\text {th }}$ and Nov $10^{\text {th }}$. The increase in plant height may be attributed due to high temperature availability at sowing time of chick pea on Oct $25^{\text {th }}$ as compared to at sowing time of chick pea on Nov $10^{\text {th }}$. The combining effect of date of sowing and seed rate levels was found to be significant for the plant height. The maximum plant height was recorded in $\mathrm{D}_{2} \mathrm{~S}_{2}$ (date of sowing in Oct $25^{\text {th }}$ with seed rate62.5@kg/ha).

Significantly highest number of primary branches/plant was recorded with seed rate of $62.5 \mathrm{~kg} / \mathrm{ha}$ than other seed rate treatments i.e. 37.5 and $87.5 \mathrm{~kg} / \mathrm{ha}$. Maximum number of primary branches/plant was observed in chickpea sown on Oct $25^{\text {th }}$ than other sowing dates i.e. Oct $10^{\text {th }}$ and Nov $10^{\text {th }}$. The more number of primary branches of chickpea in $S_{2}$ (seed rate @ $62.5 \mathrm{~kg} / \mathrm{ha}$ ) may be attributed to specific space available for better plant growth as compared to seed rate @ $37.5 \mathrm{~kg} / \mathrm{ha}$ and $87.5 \mathrm{~kg} / \mathrm{ha}$. The interaction effect of date of sowing and seed rate was found to be nonsignificant for the no. of primary branches/plant. The variation in the above mentioned growth parameters have also been reported by Aziz and Raman (1996), Yadav et al., (1999), Chaitanya and Chandrika (2006) and Mahse et al., (2006). 


\section{Phenology}

The data revealed that crop sown on Oct $10^{\text {th }}$ took more time to flowering as compared to other sowing dates i.e. Oct $25^{\text {th }}$ and Nov $10^{\text {th }}$ (Table 2). The data further revealed that seed rate @ $87.5 \mathrm{~kg} / \mathrm{ha}$ took significant more time to $50 \%$ flowering than other seed rates @ $62.5 \mathrm{~kg} / \mathrm{ha}$ and $37.5 \mathrm{~kg} / \mathrm{ha}$. Interaction effect between date of sowing and seed rate on 50\% flowering of chickpea. The maximum days taken to $50 \%$ flowering was recorded in $\mathrm{D}_{1} \mathrm{~S}_{3}$ (date of sowing in Oct $10^{\text {th }}$ with seed rate 87.5 @ kg/ha).

The early date of sowing took more time to maturity of chickpea. Maximum time taken for maturity was observed in case of sowing of chick pea on Oct $10^{\text {th }}$ than other sowing dates i.e. Oct $25^{\text {th }}$ and Nov $10^{\text {th }}$. The data further elucidated that plots with seed rate of chick pea@87.5 kg/ha took more time to maturity as compared to seed rate of chick pea @ $37.5 \mathrm{~kg} / \mathrm{ha}$ and $62.5 \mathrm{~kg} / \mathrm{ha}$. The interaction effect between date of sowing and seed rate was significant. The maximum days taken to maturity was recorded in $\mathrm{D}_{1} \mathrm{~S}_{3}$ (date of sowing in Oct $10^{\text {th }}$ with seed rate 87.5@ $\mathrm{kg} / \mathrm{ha}$ ). The variation in the above mentioned phenology parameters have also been reported by Kumar et al., (2001), Sugui and Sugui (2002) and Valimohammadi (2007) (Table 3).

\section{Yield attributes of chickpea}

Significantly highest number of fruit branches/plant was recorded with seed rate of $62.5 \mathrm{~kg} / \mathrm{ha}$ than other seed rate treatments i.e. 37.5 and $87.5 \mathrm{~kg} / \mathrm{ha}$ (Table 4). Maximum number of fruit branches/plant was observed in chickpea sown on Oct $25^{\text {th }}$ than other sowing dates i.e. Oct $10^{\text {th }}$ and Nov $10^{\text {th }}$. The interaction effect of date of sowing and seed rate was found to be non-significant for the number of fruit branches/plant.
The highest number of pods/ plant was observed in chickpea sown on Oct $25^{\text {th }}$ followed by Oct $10^{\text {th }}$ and Nov $10^{\text {th }}$. The data further indicated that seed rate of chick pea @ $62.5 \mathrm{~kg} / \mathrm{ha}$ gave significantly higher the number of pods/plant than $37.5 \mathrm{~kg}$ and 87.5 $\mathrm{kg} / \mathrm{ha}$ seed rate. The interaction effect of date of sowing and seed rate was found to be significant. The maximum number of pods were recorded in $\mathrm{D}_{2} \mathrm{~S}_{2}$ (date of sowing on Oct $25^{\text {th }}$ with seed rate of chickpea @ $62.5 \mathrm{~kg} / \mathrm{ha}$ ). The significantly maximum number of grains/pod was recorded in $\mathrm{S}_{2}$ (seed rate @ $62.5 \mathrm{~kg} / \mathrm{ha}$ ). The different date of sowing of chickpea had significant effect on the number of grains/pod. The significantly higher number of grains/pod was recorded in date of sowing of chickpea sown on Oct $25^{\text {th }}$. The interaction effect of date of sowing of chickpea and seed rate was found to be significant. The number of grains/pod found significantly higher in $\mathrm{D}_{2} \mathrm{~S}_{2}$ (date of sowing of chickpea on Oct $25^{\text {th }}$ with seed rate @ 62.5 $\mathrm{kg} / \mathrm{ha}$ ). The data showed that thousand grain weights of chickpea was significantly higher in crop sown on Oct $25^{\text {th }}$ as compared to Oct $10^{\text {th }}$ and Nov $10^{\text {th }}$. Similarly, among different seed rates maximum thousand grain weight in seed rate@62.5 kg/ha as compared to other seed rates @ 37.5 and $87.5 \mathrm{~kg} / \mathrm{ha}$. The interaction effect between date of sowing and seed rate on 1000 grain weight was significant in chickpea.

\section{Yield of chickpea}

The highest seed yield was observed in seed rate @ $62.5 \mathrm{~kg} / \mathrm{ha}$ treatment which was significantly higher than other seed rates i.e. 37.5 and $87.5 \mathrm{~kg} / \mathrm{ha}$ (Table 4). The sowing of chickpea on Oct $25^{\text {th }}$ gave significantly higher seed yield over sowing of chickpea in Oct $10^{\text {th }}$ and sowing of chickpea in Nov $10^{\text {th }}$. The increase in seed yield is attributed to sufficient storage of soil moisture, temperature and nutrient uptake, better plant 
growth in case of optimum time of sowing of chickpea which resulted in higher number of fruit branches, number of pods/plant and 1000 -grain weight.

Table.1 Effect of date of sowing and seed rate on growth parameters of chickpea

(Pooled data over two years)

\begin{tabular}{|c|c|c|c|}
\hline Treatment & $\begin{array}{c}\text { Plant } \\
\text { population } / \mathbf{m}^{2}\end{array}$ & Plant height (cm) & $\begin{array}{l}\text { No. of primary } \\
\text { branches/plant }\end{array}$ \\
\hline \multicolumn{4}{|l|}{ Date of sowing } \\
\hline October 10 & 15.0 & 59.0 & 3.5 \\
\hline October 25 & 15.2 & 61.2 & 4.1 \\
\hline November 10 & 14.8 & 56.2 & 3.0 \\
\hline $\mathrm{CD}(\mathrm{P}=\mathbf{0 . 0 5})$ & 0.13 & 0.27 & 0.12 \\
\hline \multicolumn{4}{|l|}{ Seed rate $(\mathrm{kg} / \mathrm{ha})$} \\
\hline 37.5 & 12.6 & 58.4 & 3.1 \\
\hline 62.5 & 14.7 & 61.6 & 4.0 \\
\hline 87.5 & 17.8 & 56.4 & 3.5 \\
\hline $\operatorname{LSD}(\mathbf{P}=0.05)$ & 0.12 & 0.31 & 0.13 \\
\hline Interaction & NS & 0.54 & NS \\
\hline
\end{tabular}

Table.2 Effect of date of sowing and seed rate on days taken to 50\% flowering of chickpea (Pooled data over two years)

\begin{tabular}{|c|c|c|c|c|}
\hline \multirow{3}{*}{$\begin{array}{l}\text { Date of } \\
\text { sowing }\end{array}$} & \multicolumn{3}{|c|}{ Days taken to $50 \%$ flowering } & \multirow{3}{*}{ Mean } \\
\hline & \multicolumn{3}{|c|}{ Seed rate $(\mathrm{kg} / \mathrm{ha})$} & \\
\hline & 37.5 & 62.5 & 87.5 & \\
\hline October 10 & 98.3 & 101.3 & 104.7 & 101.4 \\
\hline October 25 & 94.0 & 96.7 & 99.7 & 96.8 \\
\hline $\begin{array}{l}\text { November } \\
10\end{array}$ & 85.7 & 89.3 & 93.3 & 89.4 \\
\hline Mean & 92.7 & 95.8 & 98.2 & \\
\hline LSD $(P=0.0$ & \multicolumn{3}{|c|}{ Date of sowing: 1.06} & xS) : 0. \\
\hline
\end{tabular}

Table.3 Effect of date of sowing and seed rate on days taken to $50 \%$ maturity in chickpea

(Pooled data over two years)

\begin{tabular}{|c|c|c|c|c|}
\hline \multirow{2}{*}{$\begin{array}{c}\text { Date of } \\
\text { sowing }\end{array}$} & \multicolumn{4}{|c|}{ Days taken to maturity } \\
\cline { 2 - 5 } & $\mathbf{3 7 . 5}$ & $\mathbf{6 2 . 5}$ & $\mathbf{8 7 . 5}$ & \multirow{2}{*}{ Mean } \\
\hline October 10 & 157.3 & 160.3 & 164.3 & 160.7 \\
\hline October 25 & 151.7 & 155.3 & 159.3 & 155.4 \\
\hline November 10 & 146.3 & 149.3 & 151.7 & 149.1 \\
\hline Mean & 151.8 & 155.0 & 158.4 & \\
\hline LSD (P=0.05) & Date of sowing: $\mathbf{0 . 7 9}$ & Seed rate: $\mathbf{0 . 6 0}$ & Interaction: $\mathbf{1 . 0 5}$ \\
\hline
\end{tabular}


Table.4 Effect of date of sowing and seed rate on yield and yield attributes of chickpea (Pooled data over two years)

\begin{tabular}{|c|c|c|c|c|c|c|c|c|}
\hline Treatment & $\begin{array}{c}\text { No. of } \\
\text { fruit } \\
\text { branches } \\
\text { / plant }\end{array}$ & $\begin{array}{c}\text { No. of } \\
\text { pods per } \\
\text { plant }\end{array}$ & $\begin{array}{l}\text { No. of } \\
\text { grains } \\
\text { per pod }\end{array}$ & $\begin{array}{c}\text { 1000- } \\
\text { grain } \\
\text { weight } \\
\text { (g) }\end{array}$ & $\begin{array}{l}\text { Seed } \\
\text { yield } \\
\text { (q/ha) }\end{array}$ & $\begin{array}{c}\text { Haulm } \\
\text { yield } \\
\text { (q/ha) }\end{array}$ & $\begin{array}{c}\text { Biological } \\
\text { yield } \\
\text { (q/ha) }\end{array}$ & $\begin{array}{c}\text { Harvest } \\
\text { index }(\%)\end{array}$ \\
\hline \multicolumn{9}{|l|}{ Date of sowing } \\
\hline October 10 & 15.2 & 135.5 & 1.77 & 157.8 & 18.7 & 28.5 & 47.2 & 39.5 \\
\hline October 25 & 17.2 & 144.7 & 1.90 & 160.4 & 20.1 & 30.2 & 50.3 & 39.9 \\
\hline November 10 & 14.1 & 124.4 & 1.60 & 154.1 & 17.3 & 27.4 & 44.6 & 38.7 \\
\hline $\operatorname{LSD}(\mathbf{P}=\mathbf{0 . 0 5})$ & 0.19 & 0.38 & 0.06 & 0.40 & 0.35 & 0.43 & 0.58 & 0.52 \\
\hline \multicolumn{9}{|c|}{ Seed rate $(\mathrm{kg} / \mathrm{ha})$} \\
\hline 37.5 & 14.3 & 131.0 & 1.62 & 154.2 & 17.3 & 27.6 & 44.8 & 38.4 \\
\hline 62.5 & 16.6 & 138.7 & 1.92 & 161.0 & 20.4 & 28.5 & 48.9 & 41.7 \\
\hline 87.5 & 15.5 & 135.1 & 1.73 & 157.1 & 18.4 & 30.0 & 48.4 & 38.1 \\
\hline $\operatorname{LSD}(\mathbf{P}=0.05)$ & 0.20 & 0.42 & 0.02 & 0.45 & 0.29 & 0.25 & 0.32 & 0.46 \\
\hline Interaction & NS & 0.72 & 0.04 & 0.78 & 0.50 & 0.43 & 0.55 & 0.79 \\
\hline
\end{tabular}

The interaction effect of date of sowing of chickpea and seed rate was also significant with respect to the seed yield. Crop sown Oct $25^{\text {th }}$ with using seed rate @ $62.5 \mathrm{~kg} / \mathrm{ha}$ recorded the maximum seed yield than other treatments. The haulm yield was significantly higher in date of sowing of chickpea on Oct $25^{\text {th }}$ than other sowing dates i.e. Oct $10^{\text {th }}$ and Nov $10^{\text {th }}$.

The haulm yield was significantly higher in seed rate@ $@ 87.5 \mathrm{~kg} / \mathrm{ha}$ than other seed rates treatments i.e. 37.5 and $62.5 \mathrm{~kg} / \mathrm{ha}$. The interaction effect of date of sowing of chickpea and seed rate was also found significant. Crop sown on Oct $25^{\text {th }}$ with seed rate @ $87.5 \mathrm{~kg} /$ acre produced the maximum haulm yield than other treatments. The significantly higher biological yield was recorded in date of sowing on Oct $25^{\text {th }}$ than other sowing dates i.e. Oct $10^{\text {th }}$ and Nov $10^{\text {th }}$. The highest biological yield was recorded in the seed rate@62.5 kg/ha than other seed rates i.e. 37.5 and $87.5 \mathrm{~kg} / \mathrm{ha}$. The interaction effect of date of sowing and seed rate on biological yield was also found to be significant. The maximum yield was recorded in treatment $\mathrm{D}_{2} \mathrm{~S}_{2}$ (date of sowing on Oct $25^{\text {th }}$ with seed rate @ (62.5 kg/acre) than other treatments.

The highest harvest index (HI) was found in date of sowing on Oct $25^{\text {th }}$ than other sowing dates Oct $10^{\text {th }}$ and Nov $10^{\text {th }}$. The different seed rates had significant effect on harvest index. The treatment seed rate @ 62.5kg/ha showed the highest $(\mathrm{HI})$ than other seed rates treatments i.e. 37.5 and $87.5 \mathrm{~kg} / \mathrm{ha}$.

The interaction effect of date of sowing and seed rate on harvest index was also significant. The treatment $\mathrm{D}_{2} \mathrm{~S}_{2}$ (date of sowing on Oct $25^{\text {th }}$ with seed rate @ 62.5 $\mathrm{kg} / \mathrm{ha}$ ) recorded the highest harvest index than other treatments. On the perusal of data, it is clear that for obtaining higher seed yield of chickpea, sowing of chickpea on Oct $25^{\text {th }}$ with seed rate of $62.5 \mathrm{~kg} / \mathrm{ha}$ seems optimum. The yield reduction under late sowing dates have been similar results were also reported earlier by also Srivastava et al., (1990), Paikaray and Misra (1992), Singh and Dixit (1992), Dixit et al., (1993) and Singh et al., (1988). 
In conclusion, the growth and yield parameters were higher in Oct $25^{\text {th }}$ date of sowing than the other date of sowing i.e. Oct $10^{\text {th }}$ and Nov $10^{\text {th }}$. The seed rate @ 62.5kg/ha gave better growth and yield parameters than the other seed rate@ 37.5 and $87.5 \mathrm{~kg} / \mathrm{ha}$. Crop sown on Oct $25^{\text {th }}$ and using seed rate @ $62.5 \mathrm{~kg} / \mathrm{ha}$ seems optimum for obtaining higher seed yield.

\section{References}

Aziz, M.A. and Rahman, M.V. (1996). Effect of date of sowing on yield and yield components of Kabuli gram (Cicer arietinum L.). Indian Journal of Agriculture Science, 64(9): 624-626.

Chaitanya, S.K., and Chandrika, V. (2006). Performance of chickpea varieties under varied dates of sowing in Chittoor District of Andhra Pradesh. Legume Research, 29(2): 137-139.

Kumar, Mahesh, R.C., Singh, Rakesh, Kumar, Sanjay and Singh. (2001). Effect of date of sowing and row spacing on the performance of chickpea genotypes. Haryana journal of Agronomy, 19(2): 140-141.

Mahse, L.B., Beshmukh D.V., and. Jamadagni, B.M. (2006). Varietal improvement of chickpea for rainfed and late sown conditions. Annual Review of Plant Physiology, 20(2): 177-180.

Paikaray, R.K., and Misra, R.C. (1992).
Performance of chickpea under different dates of sowing in the Esatern Ghat Highland Zone of Orissa, India. ICN 27: 24-25.

Shrivastava, S.K., Ram Singh. and Chandrawamshi, B.R. (1990). Response of chickpea dates of sowing in Chhattisgarh Region of Madhya Pradesh. ICN 23: 26-27.

Singh, R.C., Maher, S. and Singh, M. (1988). Studies on the spacing and seed rate of small and bold seeded gram varieties under rain fed condition. Haryana Journal of Agronomy, 4(1): 28-30.

Singh, V.K., and Dixit, R.S. (1992). Effect of moisture regime and sowing date on chickpea (Cicer arietinum L.). Indian Journal of Agronomy, 37(4): 739-743.

Steel, RGD, Torrie JH. Principles and procedures of statistics: A biometrical approach. $2^{\text {nd }}$ Ed. McGraw-Hill, Singapore, 1981.

Sugui, F.P. and Sugui, C.C. (2002). Response of chickpea to dates sowing in Ilocos Norte, Philippines. ICPN 9: 13-15.

Valimohammadi, F., Tajbakhsh, M. and Saeid, A. (2007). Comparison Winter and Spring Sowing Dates and Effect of Plant Density on Yield, Yield Components and Some Quality, Morphological Traits of Chickpea (Cicer arietinum L.) Under Environmental Condition of Urmia, Iran. Journal of Agronomy, 4: 571575.

\section{How to cite this article:}

Amrinder Singh, Balwinder Singh Dhillon and Ajmer Singh Sidhu. 2019. Productivity of Chickpea (Cicer arietinum L.) under Different Sowing Date and Seed Rate in South West Punjab. Int.J.Curr.Microbiol.App.Sci. 8(05): 1419-1425.

doi: https://doi.org/10.20546/ijcmas.2019.805.162 